\title{
无酸条件下磷氭酸钠与胺反应合成磷代腿机理的密度泛函理论研究
}

\author{
李志锋 ${ }^{a} \quad$ 王文鹏 ${ }^{b} \quad$ 王喜存 ${ }^{b}$ 权正军 ${ }^{*}, b$ \\ $\left({ }^{a}\right.$ 天水师范学院化学工程与技术学院 甘肃天水 741001) \\ $(b$ 西北师范大学化学化工学院 兰州 730070)
}

\begin{abstract}
摘要 磷氰酸钠与胺可以在室温、无酸的温和条件下反应生成磷代腿. 利用密度泛函理论计算方法, 在 B3LYP/6$31 \mathrm{G}(\mathrm{d}, \mathrm{p})$ 水平上对磷氧酸钠与胺反应合成磷代腺的反应机理进行了研究, 结果表明溶剂的辅助/催化作用可以显著降低 该反应的反应势垒, 使得反应快速、高转化率发生.

关键词＼cjkstart磷氰酸钠; 磷代腿; 反应机理; 密度泛函
\end{abstract}

\section{Mechanism of Synthesis of Phosphinecarboxamides by Reaction of Sodium Phosphaethynolate Anion and Amines under Acid-Free Conditions: Density Functional Theory Investigation}

\author{
Li, Zhifeng ${ }^{a}$ Wang, Wenpeng ${ }^{b}$ Wang, Xicun ${ }^{b}$ Quan, Zhengjun* ${ }^{*, b}$ \\ ( ${ }^{a}$ College of Chemical Engineering and Technology, Tianshui Normal University, Tianshui, Gansu 741001) \\ ( ${ }^{b}$ College of Chemistry and Chemical Engineering, Northwest Normal University, Lanzhou 730070)
}

\begin{abstract}
The reaction of 2-phosphaethynolate anion and primary amines for phosphinecarboxamides synthesis using mechanochemistry has been studied using IR, ${ }^{13} \mathrm{C}$ NMR and ${ }^{31} \mathrm{P}$ NMR spectra, and the reaction occurred under grinding, mild and acid-free conditions at room temperature. In this paper, a comprehensive mechanistic density functional theory (DFT) of B3LYP/6-31G(d,p) study reveals that $\mathrm{H}$ shift can be aided/catalyzed with solvents and further the activation free energies barrier can be dramatically decreased, which is responsible for the higher yield of the product in the experiment.
\end{abstract}

Keywords 2-phosphaethynolate anion; phosphinecarboxamide; reaction mechanism; DFT

\section{Introduction}

Phosphorus plays a key role in all life processes. The phosphorus chemistry has been made great development and many fields, especially largely important catalysis reactions were discovered at the turn of the 20th century. ${ }^{[1]}$ Among the numerous phosphorus-containing compounds primary phosphines ${ }^{[2]}$ are especially interest one due to their wide variety of applications as starting materials for asymmetric catalysis, macrocyclic synthesis ${ }^{[3]}$ medicinal chemistry, ${ }^{[4]}$ and polymer science. ${ }^{[5]}$ More than, phosphinocarboxamides were applied as ligands in both smalland large-scale catalytic processes due to their unique structural versatility. ${ }^{[6]}$

$\mathrm{NaPCO}$ was first reported by Becker ${ }^{[7]}$ and has been in- vestigated by several groups recently. ${ }^{[8]}$ The unique reactivity of $\mathrm{PCO}^{-}$anion toward organic substrates leading to the generation of some very unusual compounds including inorganic and organic phosphorus-containing compounds.

Recently, Goicoechea et al ${ }^{[8 \mathrm{~d}, 9]}$ reported the novel preparation of phosphinecarboxamide and $\mathrm{N}$-alkyl phosphinecarboxamides by the addition of primary amines $\left(\mathrm{NH}_{4}^{+}\right.$, $\mathrm{RNH}_{2}$ ) into the 2-phosphaethynolate anion $\left(\mathrm{PCO}^{-}\right)$under acidic conditions, such as in the presence of pyridiniumtriflate (Py-HOTf), $\mathrm{EtNH}_{3} \mathrm{Cl}, \mathrm{HCl}$ or HOTf, which are new members of the air-stable primary phosphines. These pioneered works approached phosphinecarboxamide derivatives, which are the heavier analog of urea. However, the substrate scope is limited (only $N$-alkyl substituted phosphinecarboxamides were prepared). Additionally, some

* Corresponding author. E-mail: quanzhengjun@hotmail.com

Received March 5, 2020; revised May 17, 2020; published online May 29, 2020.

Project supported by the National Natural Science Foundation of China (Nos. 21463023, 21562036) and the Natural Science Foundation of Gansu Province (No. 17JR5RE010).

国家自然科学基金(Nos. 21463023, 21562036)和甘肃省自然科学基金(No. 17JR5RE010)资助项目. 
newly chemistry of $\mathrm{PCO}^{-}$acts as a " $\mathrm{P}$ " " transfer reagent with the release of $\mathrm{CO}$ in a variety of reactions has been discovered. ${ }^{[10]}$ Bertrand, ${ }^{[11]}$ Grutzmacher ${ }^{[12]}$ and Zhao et $a l,{ }^{[13]}$ developed serious synthetic methodologies using phosphaketenes as building blocks for novel phosphinidenes and phosphorus heterocycles. Inspired by these pioneered works, we have carried out the reasonably synthesized strategies of heaver analog of $\mathrm{N}$-aryl/alkyl-ureas and that the reaction occurred under grinding, mild and acid-free conditions at room temperature. ${ }^{[14]}$

Although the mechanism of the reaction of 2-phosphaethynolate with aryl/alkyl primary amines was investigated and the possible synthetic mechanism was proposed, ${ }^{[14]}$ why the reaction possessed rapid reaction rate, higher yield, and the mild and acid-free conditions was not clear. Therefore, to understand the title reaction deeply, we further perform a detailed theoretical analysis on its mechanism and which can further give a clue to synthesize the versatile functional phosphinecarboxamides.

\section{Computational methods}

All the structures were fully optimized at the B3LYP ${ }^{[15]}$ / BSI level [BSI: 6-31G(d,p)] because this computational method has been successfully applied in the studies. ${ }^{[16]}$ All the calculations were performed with the GAUSSIAN09 program suite. ${ }^{[17]}$ Unscaled harmonic vibrational frequency calculations were used to characterize all of the stationary points as either minima or transition states. Intrinsic reaction coordinates $(\mathrm{IRC})^{[18]}$ were employed to verify the connection of the transition states to two relevant minima. At B3LYP/BSI optimized geometries, the free energy results were refined by calculating the single point energy at the B3LYP/BSII and M062X/BSII levels (BSII: 6-311+ $+\mathrm{G}(\mathrm{d}, \mathrm{p}))$ with solvation effect. The solvent, water and acetic acid are simulated with the solvation model based on density (SMD) ${ }^{[19]}$ continuum model at the B3LYP/BSII level. The natural bond orbital (NBO) analysis was also carried out using the NBO 5.0 procedure. ${ }^{[20]}$ The Cartesian coordinates and the varied energies for all optimized structures along with the IRC cures for all translation states are listed in the supporting information.

\section{Results and discussion}

From the experiment, we examined the detailed reaction mechanisms depicted in Scheme 1. In the paper, the $X x-m$ $n / X x-m$-TS $n$ denotes the $n$th intermediate $n /$ transition state TS $n$ on the pathway $X x-m$ based on the number of assisted/catalyzed molecules $\left(\mathrm{H}_{2} \mathrm{O}\right.$ or $\left.\mathrm{AcOH}\right) m(X=\mathrm{a}, \mathrm{b} ; x=$ $1 \sim 4, m=0 \sim 4)$.

\subsection{Reactivity under proton source-free conditions}

\subsubsection{Non-aided mechanism of $\mathrm{H}_{2} \mathrm{O}$ or $\mathrm{AcOH}$}

The first event is to investigate why the mixture of $\mathrm{PCO}^{-}$(S1) and $\mathrm{PhNH}_{2}$ (S2) cannot give the product (Prod) under proton source-free conditions in the experiment without the aid of $\mathrm{H}_{2} \mathrm{O}$. The calculated geometries and energy profiles are shown in Figures 1 and 2, respectively.

As figures showing, pathway a includes two subpathways of a1-0 and a2-0. In pathway a1-0, the structure of pre-complex a1-0-1 is like experimentally proposed. The distance between $\mathrm{P}$ and $\mathrm{H}$ atoms of $\mathrm{NH}_{2}$ is $0.308 \mathrm{~nm}$ and which is comparable to the sum of the van der Waals radii for one $\mathrm{H}$ atom and one $\mathrm{P}$ atom $(0.31 \mathrm{~nm})$. This case demonstrates that the $\mathrm{H} \cdots \mathrm{P}$ hydrogen bond which is the driving force of complexation of $\mathbf{S 1}$ and $\mathbf{S 2}$, is weak. Subsequently, the reaction undergoes a1-0-TS1 (H transferring and $\mathrm{N}-\mathrm{C}$ bond-forming) $\rightarrow$ a1-0-2 $\rightarrow$ a1-0-TS2 $(\mathrm{P}-\mathrm{H}$ bond rotation) process with high activation barriers 184.6 and $185.9 \mathrm{~kJ} / \mathrm{mol}$ in $\mathrm{H}_{2} \mathrm{O}$ and $\mathrm{AcOH}$ phase, respectively. And, the system is under proton source-free conditions,

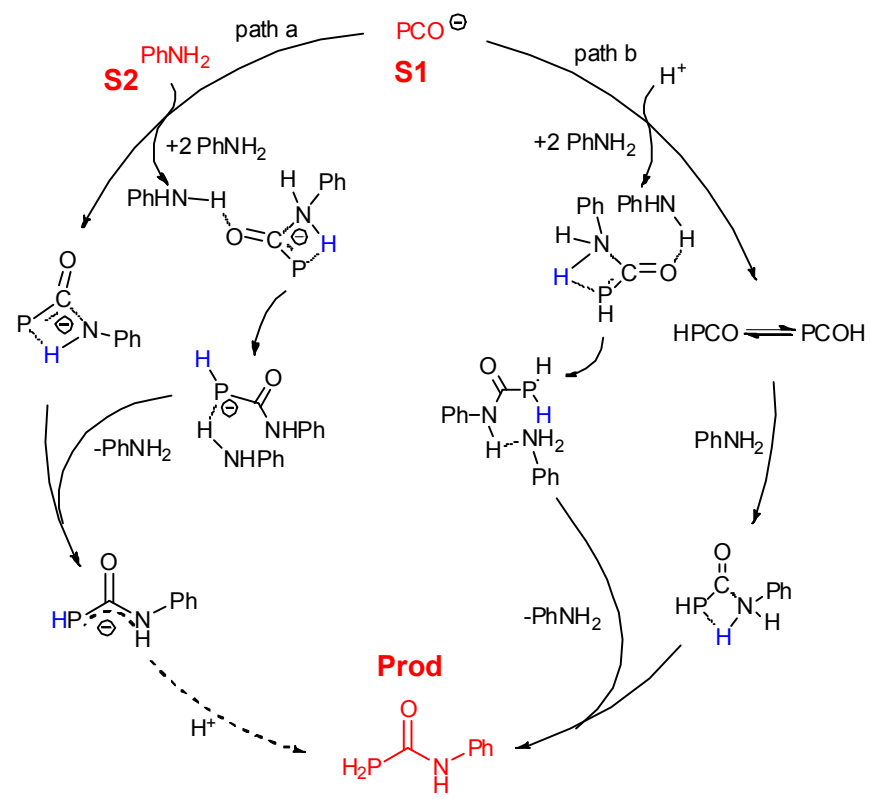

Scheme 1 Plausible mechanisms 
therefore the pathway a1-0 is terminated at the a1-0-4 and Prod is not given via path a1-0.

As above discussed, two factors prevent path a1-0 from undergoing, one is a higher activation barrier and another is a lack of the proton-donor in the system. Based on this case, we consider another reaction pathway a2-0 in which the ratio of the substrate molecule S1 with $\mathbf{S 2}$ is one to two. This performance aims to investigate whether the substrate molecule $\mathbf{S 2}$ can act as the proton-donor as well as aid system to decrease the activation barrier. The calculated geometries and energy profiles are shown in Figures 1 and 2, respectively. The activation barrier for this path is 186.3 and $184.2 \mathrm{~kJ} / \mathrm{mol} \mathrm{H}_{2} \mathrm{O}$ and $\mathrm{AcOH}$ phase, respectively. And, the calculated results show that the $\mathrm{PhNH}_{2}$ cannot afford proton in the system.

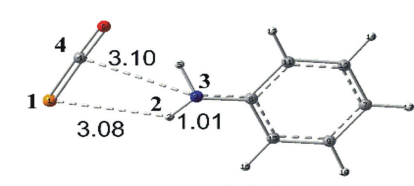

a1-0-1

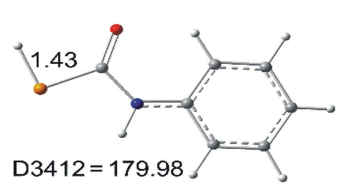

a1-0-3

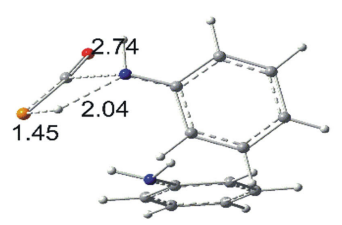

a2-0-TS1
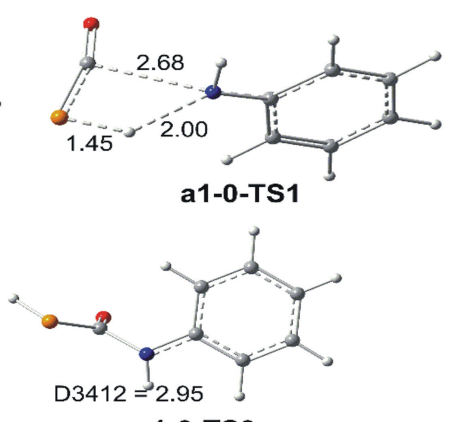

a1-0-TS3

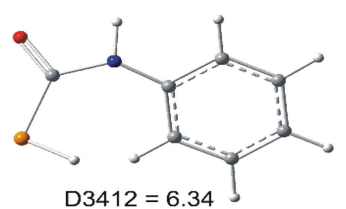

a2-0-2

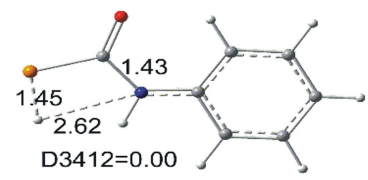

a1-0-2

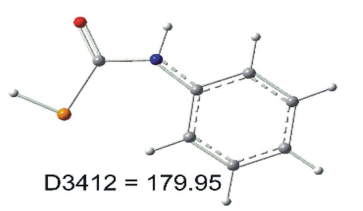

a1-0-4

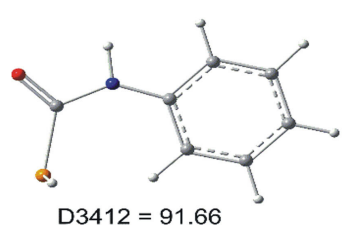

a2-0-TS2

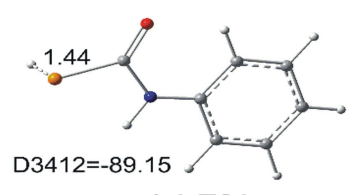

a1-0-TS2

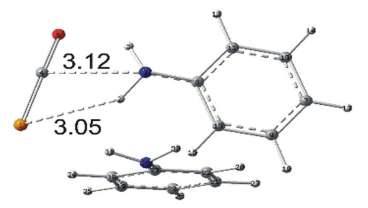

a2-0-1

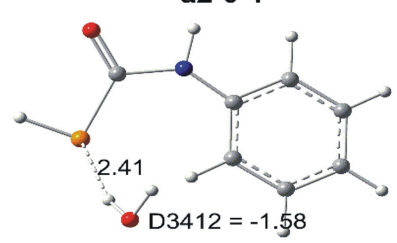

a3-0-1
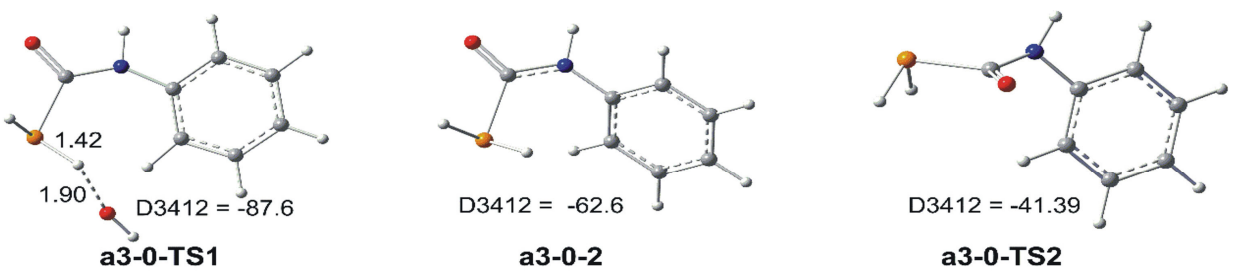

a3-0-TS2

Figure 1 Schematic diagrams of the optimized geometries for the pathways a1-0, a2-0, and a3-0 at B3LYP/BSI level (bond length: 0.1 nm, angle: ${ }^{\circ}$ )

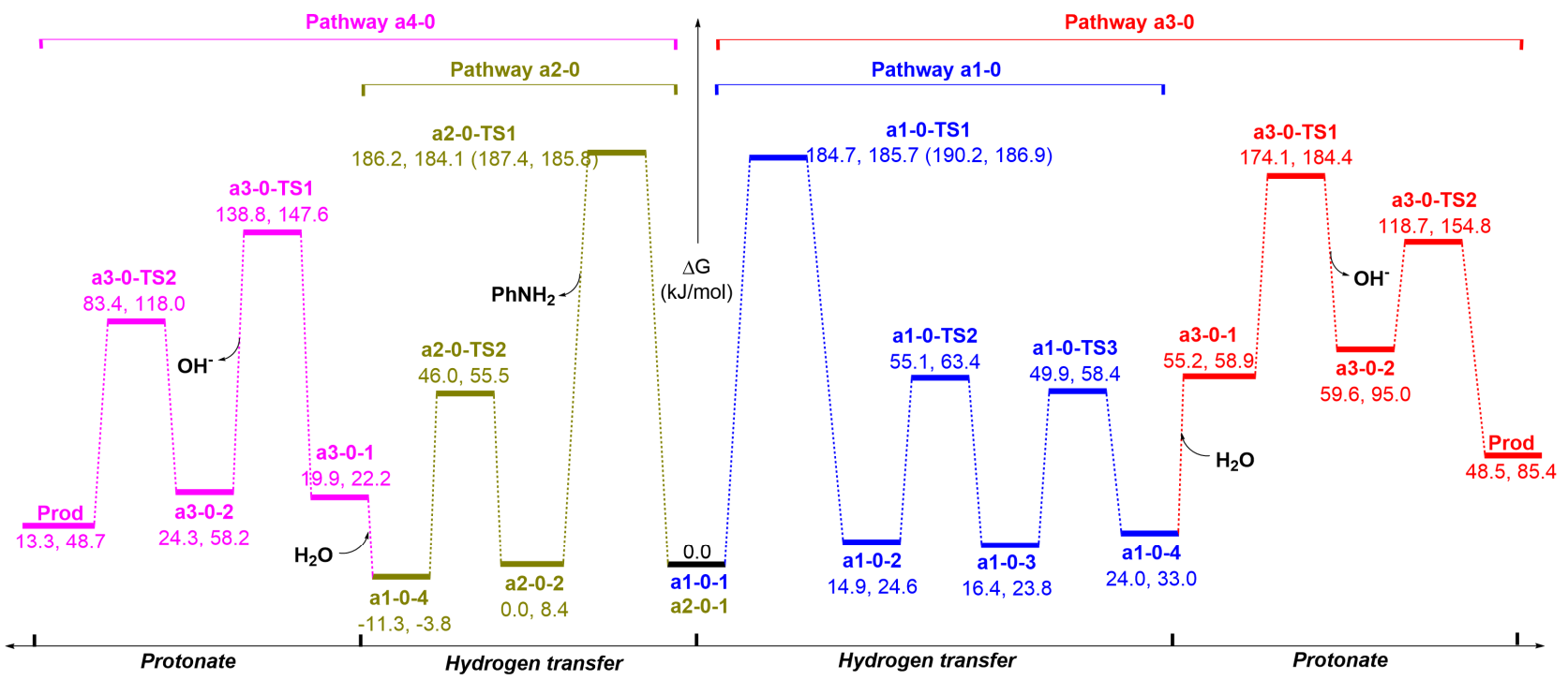

Figure 2 Free energy profiles for pathways a1-0, a2-0, a3-0, and a4-0 at B3LYP/BSII//B3LYP/BSI and M062X/BSII///B3LYP/BSI (in parentheses) levels (The parameters from left to right are in water and acetic acid phase, respectively) 
Therefore, the reaction between $\mathbf{S 1}$ and $\mathbf{S 2}$ under proton source-free case without the aid of $\mathrm{H}_{2} \mathrm{O}$ or $\mathrm{AcOH}$ is unfavored and the Prod is not given in the experiment.

\subsubsection{Aided mechanism of $\mathrm{H}_{2} \mathrm{O}$}

Another mechanistic possibility arises because the $\mathrm{H}$ shift process commonly occurs with aid (catalysis) of other functional groups or molecules, such as catalyst, ${ }^{[16 \mathrm{e}]}$ hydroxyl, ${ }^{[18 \mathrm{~b}]} \mathrm{NH}_{3}{ }^{[16 \mathrm{k}]}$ and $\mathrm{H}_{2} \mathrm{O} .{ }^{[16 \mathrm{k}, 21]}$ Inspired by these ideas, a potential mechanistic scenario $\left(\mathrm{H}_{2} \mathrm{O}\right.$-aided hydrogen shift pathway a1-m) is considered. Figures 3 and 4 showed the calculated geometries and energy profile, respectively.

As for $\mathrm{H}_{2} \mathrm{O}$ aided process, a set of pathways, (1) one $\mathrm{H}_{2} \mathrm{O}$ (pathway a1-1), (2) two $\mathrm{H}_{2} \mathrm{O}$ (pathway a1-2), (3) three $\mathrm{H}_{2} \mathrm{O}$ (pathway a1-3), or (4) four $\mathrm{H}_{2} \mathrm{O}$ molecules (pathway a1-4) are considered.
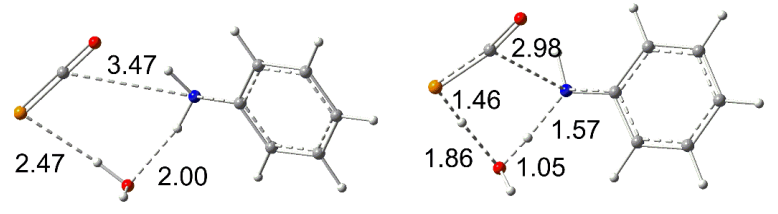

a1-1-1

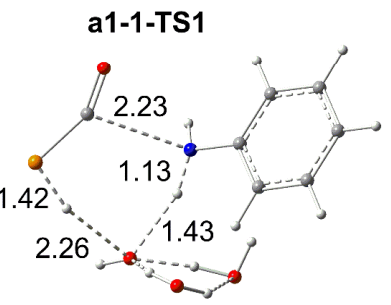

a1-3-TS1
For pathway a1-1, the $\mathrm{H}$ of $\mathrm{NH}_{2}$ shift with one water molecule aided initialed from six-member ring complex a1-1-1. In a1-1-1, one $\mathrm{H}$ of $\mathrm{NH}_{2}$ is attached by $\mathrm{O}$ atom of $\mathrm{H}_{2} \mathrm{O}$ and the $\mathrm{P}$ atom interacts with the $\mathrm{H}$ atom of $\mathrm{H}_{2} \mathrm{O}$. Triggered by interactions of $\mathrm{LP}(\mathrm{P}) \rightarrow \mathrm{LP}^{*}(\mathrm{H})(11.3 \mathrm{~kJ} / \mathrm{mol})$ and $\mathrm{LP}(\mathrm{O}) \rightarrow \mathrm{BD}^{*}(\mathrm{H}-\mathrm{N})(52.3 \mathrm{~kJ} / \mathrm{mol})$ in $\mathbf{a 1 - 1 - 1}$, the $\mathrm{H}_{2} \mathrm{O}$ as the medium of the $\mathrm{H}$-exchange spurring the $\mathrm{H}$-shift in a1-1-TS1.

From Figure 4, one can find that the assistance of a single water molecule in the proton transfer in pathway a1-1 (a1-1-TS1: $227.7 \mathrm{~kJ} / \mathrm{mol}$ ) increases the barrier heights by $43.1 \mathrm{~kJ} / \mathrm{mol}$ compared to a1-0 (a1-0-TS1: $184.6 \mathrm{~kJ} / \mathrm{mol})$ in the water phase. Notable the activated barrier gradually reduces from two to four $\mathrm{H}_{2} \mathrm{O}$ molecules involved with 144.4 (pathway a1-2), 132.3 (pathway a1-3) and 130.2
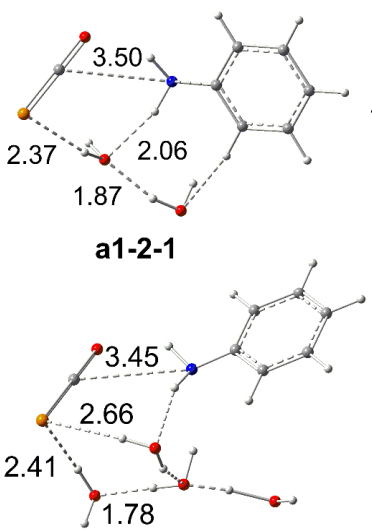

a1-4-1

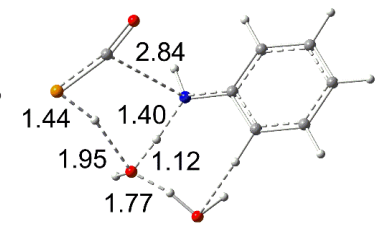

a1-2-TS1

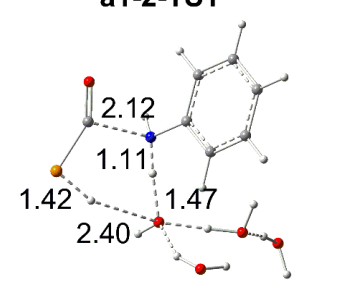

a1-4-TS1

Figure 3 Schematic diagrams of the partly optimized geometries for the pathways a1- $m$ at B3LYP/BSI level $(m=1 \sim 4$, bond length: 0.1 $\mathrm{nm})$

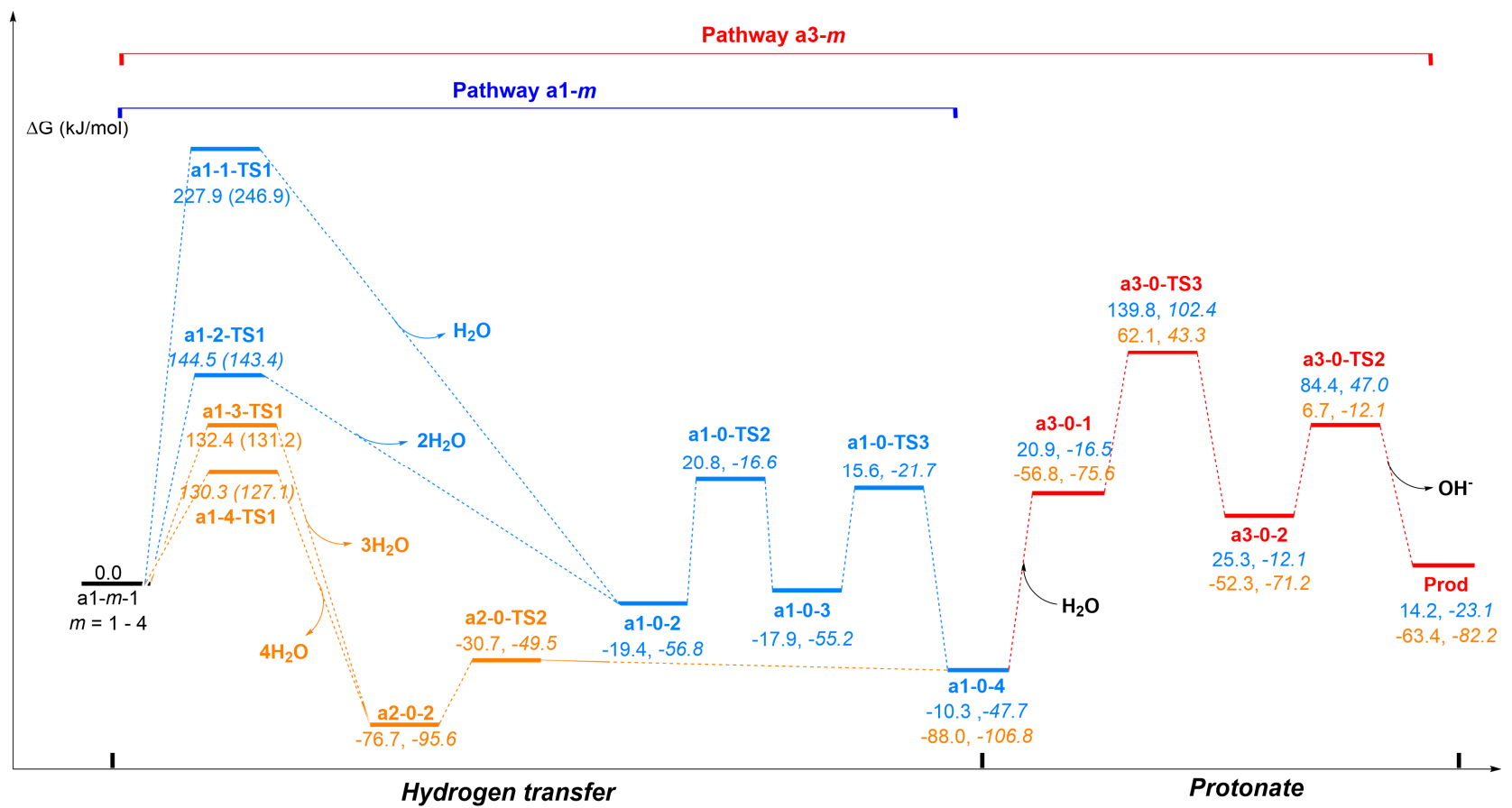

Figure 4 Free energy profiles for pathways a1- $m$ at B3LYP/BSII/B3LYP/BSI and M062X/BSII//B3LYP/BSI (in parentheses) levels $(m=1 \sim 4$, the parameters are in the water phase) 
$\mathrm{kJ} / \mathrm{mol}$ (pathway a1-4) in the reaction, by amounts 40.2 , 52.3 and $54.4 \mathrm{~kJ} / \mathrm{mol}$ contrast with that of pathway a1-0 in the water phase $(184.6 \mathrm{~kJ} / \mathrm{mol})$. Figure 4 also lists the barrier heights for a1-1-TS1 $(247.0 \mathrm{~kJ} / \mathrm{mol})$, a1-2-TS1 (143.6 $\mathrm{kJ} / \mathrm{mol})$, a1-3-TS1 (131.4 kJ/mol) and a1-4-TS1 (127.2 $\mathrm{kJ} / \mathrm{mol}$ ) at M062X/BSII//B3LYP/BSI level, and which are reasonable ones at B3LYP/BSII//B3LYP/BSI level. Based on this instance, although increasing the number of $\mathrm{H}_{2} \mathrm{O}$ molecules involved in the catalysis (to five or more molecules) is predicted to further decrease the energy barrier, their increased extent is smaller and smaller. With the aid of $\mathrm{H}_{2} \mathrm{O}$ molecule from one to four, although it can decrease the activated energy of the reaction gradually, the energy barrier of the reaction a1-4 is yet very high (above 125.6 $\mathrm{kJ} / \mathrm{mol}$ ) and therefore the detailed processes of path a1- $m$ in Figure 4 are not discussed.

\subsection{Reactivity under proton source conditions}

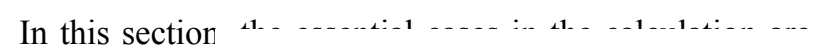
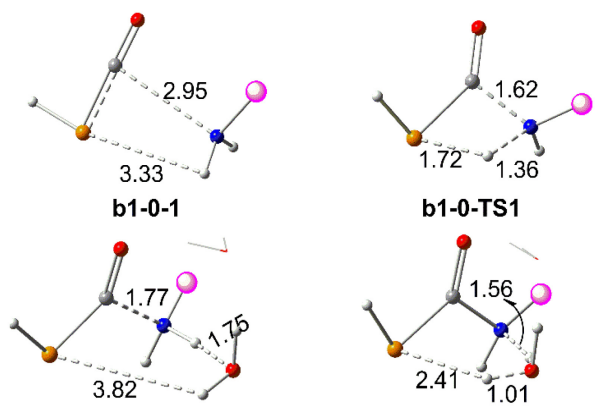

b1-0-TS1

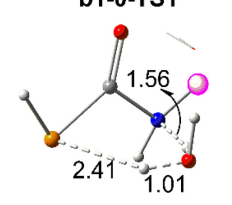

b1-2-1
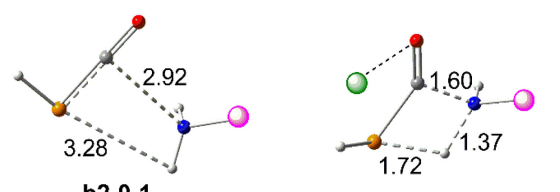

b2-0-TS1

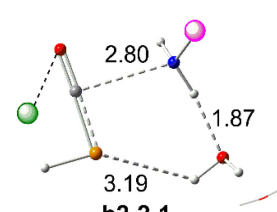

b2-2-1
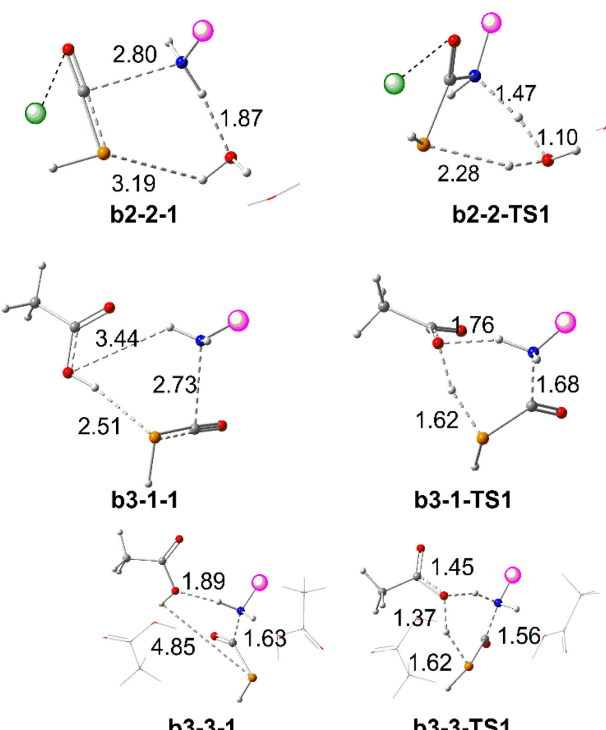

b3-1-TS1

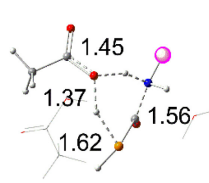

b3-3-TS1

to investigate why the Prod can be higher yielded in the experiment in presence of proton donors, such as $\mathrm{H}_{2} \mathrm{O}$ and $\mathrm{AcOH}$, comparing to under proton source-free conditions. The optimized structures and potential energy surface are presented in Figures 5 and 6, respectively.

\subsubsection{Protonation in former process}

The anion $\mathrm{PCO}^{-}$can firstly accept the proton in this case and the reaction is initialed from the neutral HPCO and $\mathbf{S 2}$.

Non-aided mechanism of $\mathrm{H}_{2} \mathrm{O}$ or AcOH: The first series pathways are the $\mathrm{H}_{2} \mathrm{O} / \mathrm{AcOH}$ non-assisted in the system (pathways b1-0, b2-0 and b3-0). As Figures 5 and 6 illustrate, pathways b1-0, b2-0 and b3-0 are similar and succinct, and they only include three steps. The first step is the complexation preliminary intermediate b1-0-1/b2-0-1/ b3-0-1 of HPCO and $\mathrm{PhNH}_{2}$, the second is the $\mathrm{H}$-transferring transition state b1-0-TS1/b2-0-TS1/b3-0-TS1 and the final is the Prod nrodiced For these nathways, the $\mathrm{H}$ -

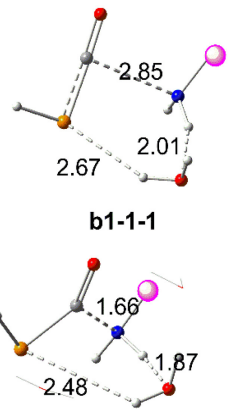

b1-3-1

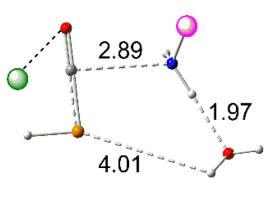

b2-1-1
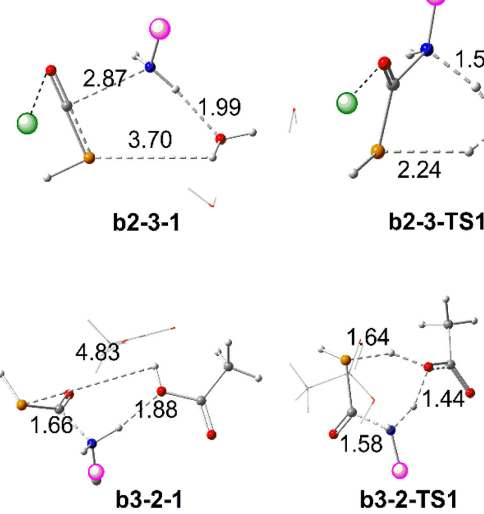

$\mathrm{O}=\mathrm{Ph}$

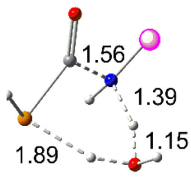

b1-1-TS1

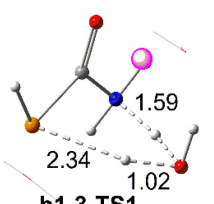

b1-3-TS1

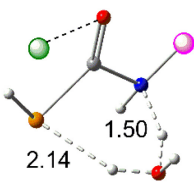

b2-1-TS1

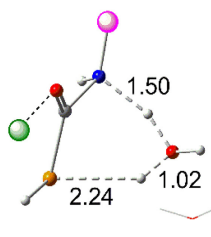

b2-3-TS1

b3-2-TS1

Figure 5 Schematic diagrams of the optimized geometries for the pathways bx- $m$ at B3LYP/BSI level $(x=1 \sim 3, m=0 \sim 3$, bond length: $0.1 \mathrm{~nm})$ 


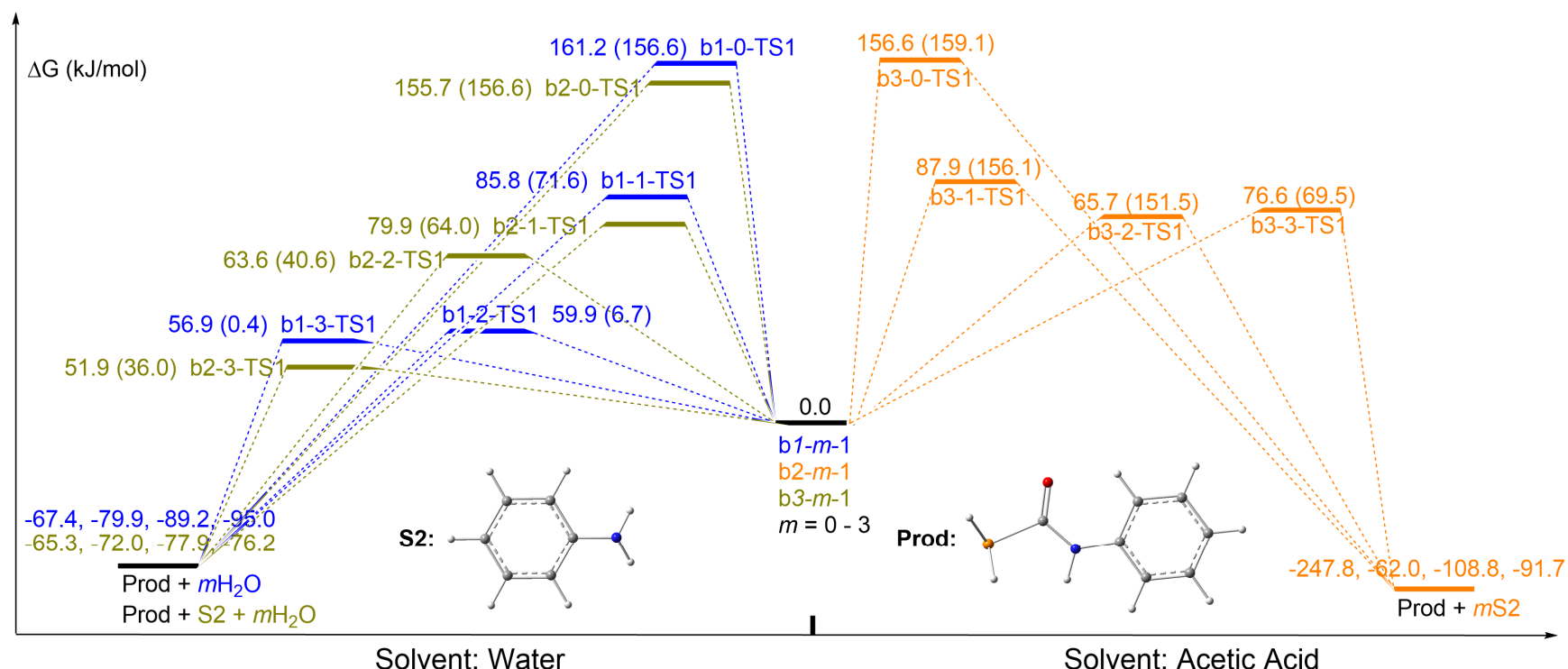

Figure 6 Free energy profiles for pathways $b x-m(x=1 \sim 3, m=0 \sim 3)$ at B3LYP/BSII/B3LYP6/BSI and M062X/BSII/B3LYP6/BSI (in parentheses) levels

final is the Prod produced. For these pathways, the Htransferring and the $\mathrm{N}-\mathrm{C}$ bond formation are concerted in b1-0-TS1/b2-0-TS1/b3-0-TS1. It is unfortunately pointed out, the activated energy is higher 161.2/155.7/156.6 $\mathrm{kJ} / \mathrm{mol}$ and the pathway $\mathrm{b} 1-0 / \mathrm{b} 2-0 / \mathrm{b} 3-0$ is unfavored, and which is inconsistent with the high yield in the experiment. When a comparison between Entries 7 and 11 in the experiment was made, ${ }^{[14]}$ the difference between them is $\mathrm{H}_{2} \mathrm{O}$ involving in Entry 7 and which leads to that giving higher yield by $43 \%$ than that of Entry 11 . Therefore, it is unambiguous that the $\mathrm{H}_{2} \mathrm{O}$ in reaction acts as a crucial role.

Aided mechanism of $\mathrm{H}_{2} \mathrm{O}$ or $\mathrm{AcOH}$ : The calculations illustrated that the reaction undergoing is strongly assisted by $\mathrm{H}_{2} \mathrm{O}$, actively participating as a catalyst in the course of the $\mathrm{H}$-shifting rearrangement. The geometries and energy profile of the $\mathrm{H}$-shifting assisted by one $\mathrm{H}_{2} \mathrm{O}$ (pathway b1-1, b2-1), two $\mathrm{H}_{2} \mathrm{O}$ (pathways b1-2 and b2-2) or three $\mathrm{H}_{2} \mathrm{O}$ (pathways b1-3 and b2-3) molecules, along with the reactant complexes. The transition structures were displayed in Figures 5 and 6 . Along the pathway b1-1, the initial six-member ring reactant complex b1-1-1 proceeds across a barrier of $85.8 \mathrm{~kJ} / \mathrm{mol}$ through transition state b1-1-TS1, giving the Prod. The $\mathrm{H}_{2} \mathrm{O}$ molecule assists the $\mathrm{H}$ shift, dramatically lowering the activation barrier by $75.3 \mathrm{~kJ} / \mathrm{mol}$ with respect to that of the non-catalytic reaction pathway b1-0 $(161.2 \mathrm{~kJ} / \mathrm{mol})$. Along the pathway b1-2, the initial HPCO $\cdots\left(\mathrm{H}_{2} \mathrm{O}\right)_{2} \cdots \mathrm{H}_{2} \mathrm{NPh}$ reactant complex b1-2-1 proceeds across a barrier of $59.9 \mathrm{~kJ} / \mathrm{mol}$ through b1-2- TS1, giving the Prod. The $\mathrm{H}_{2} \mathrm{O}$ molecule further assists the $\mathrm{H}$ shift, lowering the activation barrier by 26.0 $\mathrm{kJ} / \mathrm{mol}$ with respect to that of catalytic reaction by one $\mathrm{H}_{2} \mathrm{O}$ molecule. Three $\mathrm{H}_{2} \mathrm{O}$ molecules involved in pathway b1-3 and the reaction is initiated from complex b1-3-1, undergoing a transition state with a $56.9 \mathrm{~kJ} / \mathrm{mol}$ energy barrier to give Prod. Therefore, the $\mathrm{H}_{2} \mathrm{O}$ molecule in the system acts as the role of the catalyst which can decrease the activation barrier by $c a$. $104.6 \mathrm{~kJ} / \mathrm{mol}$ and the pathways b1-2/b1-3 are favoured in path b1. It is noteworthy that Prod is stabilized by $95.0 \mathrm{~kJ} / \mathrm{mol}$ regarding the precursor b1-3-1 (Figure 6).

The second series pathways with aid of $\mathrm{H}_{2} \mathrm{O}$ is b2- $m$, in which one HPCO and two $\mathrm{PhNH}_{2}$ molecules are involved. It can be seen from Figure 6 that the activated energies are also gradually decreased with the number of $\mathrm{H}_{2} \mathrm{O}$ molecules increased. The activated energies of paths b2-1 (79.9 $\mathrm{kJ} / \mathrm{mol})$, b2-2 $(63.6 \mathrm{~kJ} / \mathrm{mol})$ and b2-3 $(51.9 \mathrm{~kJ} / \mathrm{mol})$ are respectively similar to that of pathways b1-1 $(85.5 \mathrm{~kJ} / \mathrm{mol})$, b1-2 $(60.7 \mathrm{~kJ} / \mathrm{mol})$ and b1-3 $(56.9 \mathrm{~kJ} / \mathrm{mol})$. Therefore, pathways b1- $m$ and $b 2-m$ are no distinct difference and they are all favored in dynamics for the reaction.

Inspiring by $\mathrm{H}_{2} \mathrm{O}$ assist in Entry 7, we want to know whether the H-shift in Entry $11^{[14]}$ can be aided by $\mathrm{AcOH}$ (pathway b3-m). Figures 5 and 6 are clearly shown that $\mathrm{AcOH}$ can also assist $\mathrm{H}$-shift from $\mathrm{N}$ to $\mathrm{P}$ as well as the activated energies are $156.6 \mathrm{~kJ} / \mathrm{mol} \rightarrow 87.9 \mathrm{~kJ} / \mathrm{mol} \rightarrow 65.7$ $\mathrm{kJ} / \mathrm{mol} \rightarrow 76.6 \mathrm{~kJ} / \mathrm{mol}$ with the number of $\mathrm{AcOH}$ molecules increased from zero (pathway b3-0) to three (pathway b3-3), which illustrates that the reaction through Entry 11 can also give Prod.

It can be concluded that pathways b1 and b2 with $\mathrm{H}_{2} \mathrm{O}$ molecules aided are both occurred in Entry 7, while Entry 11 is only involved b3- $m$ with $\mathrm{AcOH}$ molecules assisted. And, pathways b1- $m$ and $b 2-m$ have lower activated energy than path b3-m. Therefore, the Entry 7 system is a three-channel reaction, and which leads to a higher yield than that of Entry 11 in the experiment. ${ }^{[14]}$

To further elucidate the mechanistic difference among the pathways b1-m, b2- $m$ and $\mathrm{b} 3-m$, the NPA (Natural Population Analysis) and NBO analysis were employed. ${ }^{[22]}$ As Figure 7 shown, the NPA charges for N3 (ca. $-0.8 e$ ) and $\mathrm{C} 4(\mathrm{ca} .0 .4 \mathrm{e})$ remained almost constant in all transition states and with the solvents $\mathrm{H}_{2} \mathrm{O} / \mathrm{AcOH}$ number increasing, the NPA charges on P1 (more negative) and $\mathrm{H} 2$ 


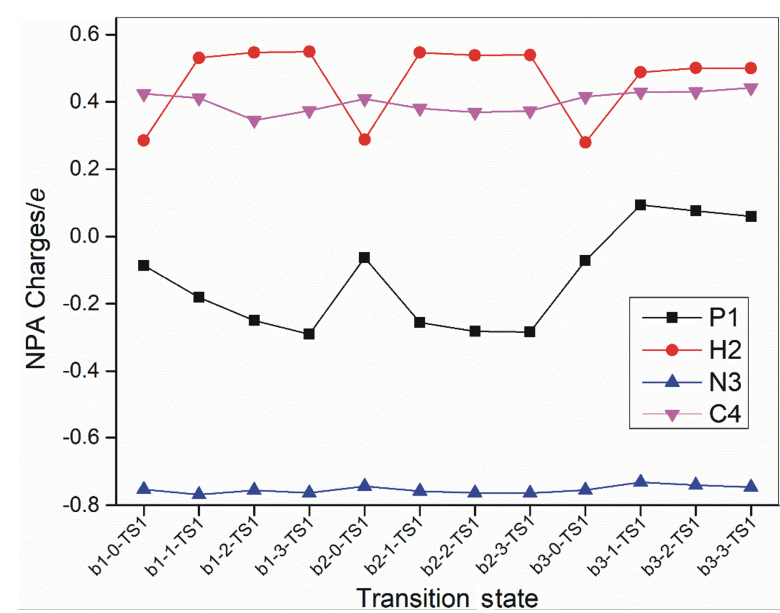

Figure 7 NPA charges for P1, H2, N3 and C4 atoms in transition states for pathways b1-m, b2-m and b3-m

(more positive) atoms in pathways b1- $m$ and b2- $m$ changed regularly. On the contrary, in b3- $m$ pathway, the NPA charges on $\mathrm{P} 1$ atom changed from negative to positive.

For pathway b1-m, the electrons transfer from $\mathrm{LP}_{\mathrm{N} 3}$ to $\mathrm{BD}_{\mathrm{P} 1-\mathrm{C} 4}^{*}$ in transition states with the secondary stabilization energy $E_{\mathrm{ij}}^{(2)}$ increasing gradually: $60.7 \mathrm{~kJ} / \mathrm{mol}$ $($ b1-1-TS1) $\rightarrow 117.2 \mathrm{~kJ} / \mathrm{mol} \quad($ b1-2-TS1) $\rightarrow 149.4 \mathrm{~kJ} / \mathrm{mol}$ (b1-3-TS1). In pathway b2- $m$, excepting b2-1-TS1 $\left(\mathrm{LP}_{\mathrm{N} 3} \rightarrow \mathrm{BD}_{\mathrm{P} 1-\mathrm{C} 4}, 110.0 \mathrm{~kJ} / \mathrm{mol}\right)$, orbitals $\mathrm{LP}_{\mathrm{N} 3}$ interacts with $\mathrm{BD}^{*}{ }_{\mathrm{C}-\mathrm{O}}\left(E_{\mathrm{ij}}{ }^{(2)}: c a\right.$. $\left.79.5 \mathrm{~kJ} / \mathrm{mol}\right)$ for both b2-2-TS1 and b2-3-TS1. The electron donors are the orbital $\mathrm{LP}_{\mathrm{O}^{-}}$ $\left(\mathrm{H}_{2} \mathrm{O}\right)$ and the electron acceptors are $\mathrm{BD}_{\mathrm{P} 1-\mathrm{H}}^{*}\left(\mathrm{H}_{2} \mathrm{O}\right)$ and $\mathrm{BD}_{\mathrm{H} 2-\mathrm{N} 3}^{*}$ in transition states of $\mathrm{b} 3-m$ pathway (Figure 8 ), which is different from those in pathways b1- $m$ and $b 2-m$. The $E_{\mathrm{ij}}{ }^{(2)}$ values of $\mathrm{LP}_{\mathrm{O}}\left(\mathrm{H}_{2} \mathrm{O}\right) \rightarrow \mathrm{BD}_{\mathrm{P} 1-\mathrm{H}}\left(\mathrm{H}_{2} \mathrm{O}\right)$ are decreased gradually whereas those of $\mathrm{LP}_{\mathrm{O}}\left(\mathrm{H}_{2} \mathrm{O}\right) \rightarrow \mathrm{BD}^{*}{ }_{\mathrm{H} 2-\mathrm{N} 3}$ are increased in the order: b3-1-TS1 $\rightarrow$ b3-2-TS1 $\rightarrow$ b3-3TS1.
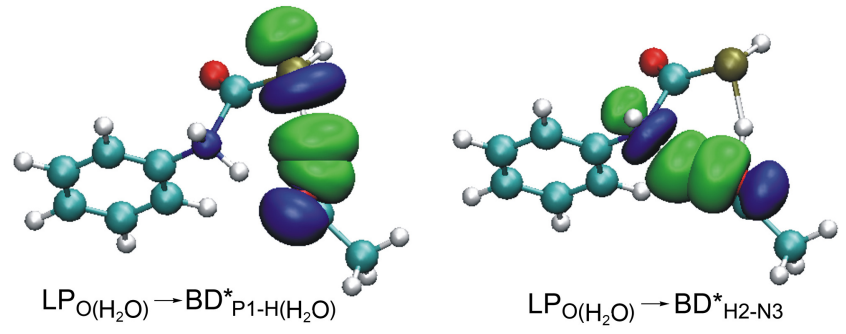

Figure 8 3D paragraph of electron transferring for b3-1-TS1

\subsubsection{Protonation in later process}

In this case, the anion $\mathrm{PCO}^{-}$can firstly complex with the substrate $\mathbf{S 2}$, and the pathway corresponding to a3/a4 .

For pathways a3-0 and a4-0 (Figures 1 and 2) without the aid of $\mathrm{H}_{2} \mathrm{O}$ molecules, although the intermediate a1-0-4 can be protonated and the final Prod can be given seemingly in the procedure, the precursor processes of a3-0 and a4- 0 are the same with the pathways a1-0 and a2-0, respectively and their activation barriers are $c a .167 .4 \mathrm{~kJ} / \mathrm{mol}$. Therefore, pathways a3-0 and a4-0 without $\mathrm{H}_{2} \mathrm{O}$ assisted are disfavored.

For the pathway a3- $m$ with aid of varies number $\mathrm{H}_{2} \mathrm{O}$ molecules $m(m=1 \sim 4)$, the a3- $m$ are also similar to a1- $m$ with the same number of $\mathrm{H}_{2} \mathrm{O}$ molecules and they have the same $\mathrm{H}$-transfer processes. The energy barriers of them are all above $30 \mathrm{~kJ} / \mathrm{mol}$ (Figure 4), which results in the later protonation that cannot perform in the subsequent procedure.

\section{Conclusions}

The reaction mechanism of 2-phosphaethynolate anion and primary amines for phosphinecarboxamides synthesis was studied by using DFT method in B3LYP/6-31G(d,p) and $\mathrm{M} 062 \mathrm{X} / 6-311++\mathrm{G}^{* *}(\mathrm{PCM}) / / \mathrm{B} 3 \mathrm{LYP} / 6-31 \mathrm{G}(\mathrm{d}, \mathrm{p})$ levels. Calculated investigating shows that the anion $\mathrm{PCO}^{-}$ is protonated firstly and the reaction is initiated from the complexation of HPCO with substrate $\mathrm{PhNH}_{2}$. Attributed to aid/catalysis with various sizes (from one to four) of solvents $\mathrm{H}_{2} \mathrm{O}$ and $\mathrm{AcOH}$ cluster, the activation free energies barrier can be dramatically decreased and the reaction has its own merits, such as rapid reaction rate, higher yield, and the mild reaction condition.

Supporting Information The Cartesian coordinates for the calculated stationary structures, and the energies for the transition and ground states obtained from the DFT calculations are given. . The Supporting Information is available free of charge via the Internet at http://sioc-journal.cn.

\section{References}

[1] (a) Solařová, H.; Císařová, I.; Štěpnička, P. Organometallics 2014, $33,4131$.

(b) Gómez Arrayás, R.; Adrio, J.; Carretero, J. C. Angew. Chem., Int. Ed. 2006, 45, 7674.

[2] (a) Hiney, R. M.; Ficks, A.; Müller-Bunz, H.; Gilheany, D. G.; Higham, L. J. Organometallic Chemistry, the Royal Society of Chemistry, London, 2011, Vol. 37, p. 27.

(b) Li, X.; Robinson, K. D.; Gaspar, P. P. J. Org. Chem. 1996, 61, 7702 .

(c) Chatterjee, S.; George, M. D.; Salem, G.; Willis, A. C. J. Chem. Soc., Dalton Trans. 2001, 1890.

(d) Herrbach, A.; Marinetti, A.; Baudoin, O.; Guénard, D.; Guéritte, F. J. Org. Chem. 2003, 68, 4897.

(e) Hoge, G.; Samas, B. Tetrahedron: Asymmetry 2004, 15, 2155. (f) Clark, T.; Landis, C. Tetrahedron: Asymmetry 2004, 15, 2123.

[3] Kyba, E. P.; Liu, S. T. Inorg. Chem. 1985, 24, 1613.

[4] Katti, K. V.; Gali, H.; Smith, C. J.; Berning, D. E. Acc. Chem. Res. 1999, 32, 9.

[5] (a) Hooper, T. N.; Huertos, M. A.; Jurca, T.; Pike, S. D.; Weller, A. S.; Manners, I. Inorg. Chem. 2014, 53, 3716.

(b) Dorn, H.; Singh, R. A.; Massey, J. A.; Nelson, J. M.; Jaska, C. A.; Lough, A. J.; Manners, I. J. Am. Chem. Soc. 2000, 122, 6669.

(c) Dorn, H.; Singh, R. A.; Massey, J. A.; Lough, A. J.; Manners, I. Angew. Chem., Int. Ed. 1999, 38, 3321.

(d) Dorn, H.; Singh, R. A.; Massey, J. A.; Lough, A. J.; Manners, I. Angew. Chem. 1999, 111, 3540 .

[6] (a) Duckmanton, P. A.; Blake, A. J.; Love, J. B. Inorg. Chem. 2005, 44, 7708 .

(b) Meeuwissen, J.; Detz, R.; Sandee, A. J.; de Bruin, B.; Siegler, M. A.; Spek, A. L.; Reek, J. N. H. Eur. J. Inorg. Chem. 2010, 2010, 2992. 
(c) Škoch, K.; Císařová, I.; Štěpnička, P. Organometallics 2016, 35 , 3378 .

[7] (a) Becker, G.; Heckmann, G.; Hübler, K.; Schwarz, W. Z. Anorg Allg. Chem. 1995, 621, 34.

(b) Becker, G.; Schwarz, W.; Seidler, N.; Westerhausen, M. Z. Anorg. Allg. Chem. 1992, 612, 72.

[8] (a) Puschmann, F. F.; Stein, D.; Heift, D.; Hendriksen, C.; Gal, Z. A.; Grützmacher, H.-F.; Grützmacher, H. Angew. Chem., Int. Ed. 2011, 50, 8420 .

(b) Jupp, A. R.; Goicoechea, J. M. Angew. Chem., Int. Ed. 2013, 52, 10064.

(c) Li, Z.; Chen, X.; Benkö, Z.; Liu, L.; Ruiz, D. A.; Peltier, J. L.; Bertrand, G.; Su, C.-Y.; Grützmacher, H. Angew. Chem., Int. Ed. 2016, 55, 6018 .

(d) Jupp, A. R.; Goicoechea, J. M. J. Am. Chem. Soc. 2013, 135, 19131.

[9] (a) Jupp, A. R.; Trott, G.; Payen de la Garanderie, É.; Holl, J. D. G.; Carmichael, D.; Goicoechea, J. M. Chem.-Eur. J. 2015, $21,8015$.

(b) Robinson, T. P.; Goicoechea, J. M. Chem.-Eur. J. 2015, 21, 5727.

[10] (a) Magnall, R.; Balázs, G.; Lu, E.; Tuna, F.; Wooles, A. J.; Scheer, M.; Liddle, S. T. Angew. Chem., Int. Ed. 2019, 58, 10215.

(b) Goicoechea, J. M.; Grützmacher, H. Angew. Chem., Int. Ed. 2018, 57, 16968.

[11] (a) Hansmann, M. M.; Bertrand, G. J. Am. Chem. Soc. 2016, 138, 15885.

(b) Liu, L.; Ruiz, D. A.; Munz, D.; Bertrand, G. Chem 2016, 1, 147.

[12] Liu, L.; Ruiz, D. A.; Dahcheh, F.; Bertrand, G.; Suter, R.; Tondreau, A. M.; Grützmacher, H. Chem. Sci. 2016, 7, 2335.

[13] Wu, Y.; Liu, L.; Su, J.; Zhu, J.; Ji, Z.; Zhao, Y. Organometallics 2016, 35, 1593.

[14] Wu, Y.-H.; Li, Z.-F.; Wang, W.-P.; Wang, X.-C.; Quan, Z.-J. Eur. J. Org. Chem. 2017, 2017, 5546.

[15] (a) Becke, A. D. Phys. Rev. A 1988, 38, 3098.

(b) Lee, C.; Yang, W.; Parr, R. G. Phys. Rev. B 1988, 37, 785.

(c) Becke, A. D. J. Chem. Phys. 1993, 98, 5648.

[16] (a) Cui, C.-X.; Chen, H.; Li, S.-J.; Zhang, T.; Qu, L.-B.; Lan, Y.
Coord. Chem. Rev. 2020, 412, 213251.

(b) Faza, O. N.; López, C. S.; Álvarez, R.; de Lera, A. R. J. Am. Chem. Soc. 2006, 128, 2434.

(c) Shi, F.-Q.; Li, X.; Xia, Y.; Zhang, L.; Yu, Z.-X. J. Am. Chem. Soc. 2007, 129, 15503.

(d) Yu, Z.-X.; Wender, P. A.; Houk, K. N. J. Am. Chem. Soc. 2004, $126,9154$.

(e) Li, Z.-F.; Fan, Y.; DeYonker, N. J.; Zhang, X.; Su, C.-Y.; Xu, H.; $\mathrm{Xu}, \mathrm{X}$; Zhao, C. J. Org. Chem. 2012, 77, 6076.

(f) Li, Z.-F.; Yang, X.-P.; Hui-Xue, L.; Guo, Z. Organometallics 2014, 33, 5101.

(g) Zhou, T.; Xia, Y. Organometallics 2014, 33, 4230.

(h) Wang, Y.; Liao, W.; Huang, G.; Xia, Y.; Yu, Z.-X. J. Org. Chem. 2014, 79, 5684.

(i) Cohen, A. J.; Mori-Sánchez, P.; Yang, W. Chem. Rev. 2012, 112, 289.

(j) Hou, C.; Jiang, J.; Zhang, S.; Wang, G.; Zhang, Z.; Ke, Z.; Zhao, C. ACS Catal. 2014, 4, 2990.

(k) Tsipis, C. A.; Karipidis, P. A. J. Am. Chem. Soc. 2003, 125 , 2307.

[17] Frisch, M. J.; Trucks, G. W.; Schlegel, G. W.; Scuseria, G. W. Gaussian 09, Revision D.01, Gaussian, Inc., Wallingford CT, 2013.

[18] (a) Fukui, K. Acc. Chem. Res. 1981, 14, 363. (b) Fukui, K. J. Phys. Chem. 1970, 74, 4161

[19] Marenich, A. V.; Cramer, C. J.; Truhlar, D. G. J. Phys. Chem. B 2009, 113, 4538 .

[20] Glendening, E. D.; Badenhoop, J. K.; Reed, A. E.; Carpenter, J. E.; Bohmann, J. A.; Morales, C. M.; Weinhold, F. NBO 5.0, Theoretical Chemistry Institute, University of Wisconsin, Madison, WI, 2001.

[21] Karton, A.; O'Reilly, R. J.; Radom, L. J. Phys. Chem. A 2012, 116, 4211.

[22] (a) Ess, D. H.; Houk, K. N. J. Am. Chem. Soc. 2008, 130, 10187. (b) Bickelhaupt, F. M.; Houk, K. N. Angew. Chem., Int. Ed. 2017, 56,10070 .

(c) Lv, X.; Zhang, X.; Sa, R.; Huang, F.; Lu, G. Org. Chem. Front. 2019, 6, 3629 .

(d) Ogunlana, A. A.; Bao, X. Chem. Commun. 2019, 55, 11127.

(Lu, Y.) 